\title{
A Commoner Said "This!" : High times, and last hours of a nobility.
}

\author{
Camille Akmut
}

\begin{abstract}
Unfinished article on Yakov Yurovsky (1878-1938), and the end of a certain nobility. A mirror to our times, as ever, always.
\end{abstract}




\section{Introduction : "been dreaming it forever", a hero, and a great old fool.}

Yakov Yurovsky (1878-1938) - our hero, we say this here with much, much pride, tenderness.

Yakov Yurovsky was born into the very bottom of society : one of ten children of 2 working-class folks, a glazier (glass worker), and a seamstress.

Yakov Yurovsky was a child of Hattie Carroll : "maid of the kitchen. She was fifty-one years old and gave birth to ten children". But, here is the truth that even Bob Dylan could never bring himself to say : Hattie Carrol had been made and killed in the kitchen, long before Zanzinger ever got there...

Yakov Yurovsky instead, like Nat Turner, caught the cane, and sent it flying back. No, the truth : they didn't wait for it.

Yakov Yurovsky came from the people, had continued to live among them as a young adult, and returned to them when he died.

Yakov Yurovsky found the courage to do what many thought, few could bring themselves to say out loud, and some couldn't even think or imagine anymore, even in their wildest dreams : where the shackles of the mind, that are the worst, had extended, and become so strong and deep, that dreams had become empty.

"The true story of the martyrdom of Nicholas II, ex-Tsar of Russia, and of his wife and family can at last be told."

Only an imbecile of the kind of Robert Milton could conceive of these events in such terms.

He did so in the opening of The Last Days of the Romanovs, a book published shortly after the events, in 1920; a book not unrepresentative of the attitudes of the time, including that of Winston Churchill most notably perhaps, who wrote - he with no restraint certainly - that :

There is no need to exaggerate the part played in the creation of Bolshevism and in the actual bringing about of the Russian Revolution by these international and for the most part atheistical Jews. ${ }^{1}$

Choose your heroes well.

Winston Churchill came from the very top of our society : born inside a palace, just like the Romanovs; Blenheim Palace in Oxfordshire.

In many photos, you can see him posing - here in dress uniform, there in tuxedo suit - in the manner characteristic of his class.

Origins such that they made him forget what the rest of society was, and looked like.

And, how could he know?

${ }^{1}$ Weber 1993 : viii. 
"Those less fortunate" said, and continue to say, and think people like him, in euphemisms so big they can only be products of minds and social origins like his.

This was so, of course, only until unlikely figures such as Yurovsky made equally unlikely appearances in their houses, and kicked the doors of their palaces open. And, boy oh boy, what a surprise then!

The serveants, who had almost no choice but to be what they had made them to be, suddenly recognized him as one of them, and simultaneously their true situation in the great whole unfolding.

Winston Churchill, this great old fool, had preferred concentrating on ethnicity/religion over social class. - It is not difficult to see why now.

And, we know many of our contemporary historians to be like him anything, but social classes, in their strange analyses. We also know why, namely for the same exact reasons; same origins.

Except, there was nothing that came even close to elite as "international" about Yurovsky, who was born in the Middle of Russia; except that he had traveled all the way West to the Ipatiev House.

And, he had abandoned religion, because he had read Marx.

As retold by Yakov :

On the 16th in the morning I dispatched the little cook, the boy Sednev, under the pretext that there would be a meeting with his uncle who had come to Sverdlovsk. (...) I prepared 12 revolvers and designated who would shoot whom. Comrade Filipp [Goloshchyokin] told me that a truck would arrive at midnight; the people coming would say a password; (...) At about 11 o'clock at night on July 16 I assembled the men again, handed out the revolvers $(\ldots)$

I said to Nicholas approximately this: His royal and close relatives inside the country and abroad were trying to save him, but the Soviet of Workers' Deputies resolved to shoot them. He asked "What?" and turned toward Alexei. At that moment I shot him and killed him outright. He did not get time to face us to get an answer. (...)

In the evening of the 19 th I went to Moscow with my report.

Nicholas II was utterly perplexed, and asked Yurovsky "What? What?"; Yurovsky responded by saying "This!", and shot him straight in the face ${ }^{2}$.

\footnotetext{
${ }^{2}$ In the chest they say, but here we hear our own songs too, and prefer to think he had aimed for the head, instead / in fact.
} 


\section{Epilog}

This is perhaps the ultimate fate of all "nobilities", new and old, of this world.

"The ... nobles and soon-to-be bourgeois" writes Jacques Le Goff.

In Virginia, they had pointed a shotgun at Nat Turner, who drew a knife from his side.

Our masters are never more perplexed than when we finally live up to our roles, drag them across lands and streets, plantations and offices : " $b y$ the innards", these not-so gentle Enlightenment philosophers still found the courage to say in the 18th century, by the rope they did us in, in the 19th century, by fire in the Middle Ages of queers; and, by the collar or necktie we would say, or do now. - as they had kept us on leashes.

"Tragedy", say modern-day Royal historians, like Figes or Rappaport; "martyrdom" said Wilton. But, for whom?

Our people danced, laughed, in those brief moments of liberation.

\section{References}

"A solid understanding of history is the best guide to comprehending the present and anticipating the future. Accordingly, people are most interested in historical questions during times of crisis, when the future seems most uncertain." writes Mark Weber acutely - if this law of history holds, these questions and events should play no greater role than now.

—. 2019. "Average intellectuals' and the Middle ages : an introduction with translation, and apparatus."

Marx, Karl and Engels, Friedrich. [1848]. The Communist Manifesto.

Smith, S. A.. 2002. The Russian Revolution: A Very Short Introduction. Oxford University Press.

Weber, Mark. 1993. "Introduction". In : Wilton, Robert. The Fate of the Romanovs. Institute for Historical Review, pp. v-xvii. 